\title{
VARIASI PERBEDAAN JUMLAH DENYUT NADI PENYELAM TRADISIONALPADA SIMULASI PENYELAMAN
}

\author{
Rheiner V.Mandagi, Maya Moningka, Jimmy Rumampuk \\ Bagian Fisika Fakultas Kedokteran Universitas Sam Ratulangi Manado
}

\begin{abstract}
Human dive response aims to conserve oxygen. Direct contact of the water on the forehead, eyes and nose is a strong stimulus for which is innervated by the trigeminal nerve stimulation causes inhibition against respiratory and vasomotor centers and the activation of cardiac vagal motoneuron. The cardiovascular response that causes a decrease in the heart rate and vasoconstriction Facial cold receptors more strongly activated by low water temperature $\left(10-15^{0} \mathrm{C}\right)$. The specific objective of this study was to analyze differences in pulse number of healthy male traditional diver before, while, and after simulated dives. This research is an experimental study with 20 analytical samples are housed in Malalayang 2 Data were analyzed using SPSS and Test T. The results of this study found the number of pulses during a breath hold and facial immersion in cold water was significantly lower than that before doing the activity ( $p=0.0001$ ) with 17.1 \pm 10.2 difference. The number after the pulse raised face of the water was significantly higher than the current hold your breath and facial immersion in cold water ( $p=0.0001$ ), with the difference in the amount of as much as $16.6 \pm 10.8$ pulse. Conclusion : there are significant difference $(p=0.0001)$ number of pulses in healthy male traditional divers during the interim before and after the while doing simulations hold your breath and dive with facial immersion in cold water.
\end{abstract}

Keywords : Pulse, Traditional Diving

Abstrak.Respon penyelaman manusia bertujuan untuk menghemat oksigen.Kontak langsung terhadap air pada dahi, mata dan hidung merupakan stimulus kuat karena dipersarafi oleh nervus trigeminus dimana stimulasi terhadapnya menyebabkan penghambatan pernafasan dan pengaktifan pusat vasomotor dan motoneuron vagal jantung.Respon kardiovaskuler ini yang menyebabkan penurunan denyut jantung dan terjadinya vasokontriksi.Reseptor dingin wajah lebih kuat teraktivasi dengan air temperatur rendah $\left(10-15^{0} \mathrm{C}\right)$. Tujuan khusus penelitian ini adalah menganalisa perbedaan jumlah denyut nadi laki-laki sehat penyelam tradisional sebelum, sementara, dan sesudah simulasi penyelaman.Penelitian ini merupakan jenis penelitian analitik eksperimental dengan 20 sampel yang bertempat di Malalayang 2. Data dianalisis dengan menggunakanSPSS dan Uji T. Hasil penelitian ini didapatkan jumlah denyut nadi saat melakukan tahan napas dan perendaman wajah dalam air dingin secara bermakna lebih rendah dibandingkan dengan sebelum melakukan kegiatan tersebut $(\mathrm{p}=0,0001)$ dengan perbedaan sebanyak 17,1+10,2. Jumlah denyut nadi sesudah wajah diangkat dari dalam air bermakna lebih tinggi daripada saat tahan napas dan perendaman wajah dalam air dingin $(p=0,0001)$, dengan perbedaan jumlah denyut nadi sebanyak 16,6+10,8. Simpulan: ada perbedaan bermakna $(\mathrm{p}=0,0001)$ jumlah denyut nadi pada laki-laki sehat penyelam tradisional pada saat sebelum dengan sementara dan sesudah dengan sementara melakukan simulasi penyelaman dengan tahan napas dan perendaman wajah dalam air dingin.

Kata Kunci: Denyut Nadi, Penyelaman Tradisional. 
Menyelam adalah aktivitas bawah air yang sukar dan dapat mempengaruhi struktur dan fungsi tubuh. Penyelam akan terpajan oleh beberapa faktor selama penyelaman seperti risiko tenggelam, turunnya suhu dan peningkatan tekanan lingkungan. Semua hal ini akan berpengaruh terhadap perubahan hemodinamik. ${ }^{1}$

Penyelaman pada hakekatnya merupakan aktivitas manusia di lingkungan lebih dari satu atmosfer absolut yang dapat berbentuk udara/gas bertekanan atau di dalam air. “Stresor” berupa meningkatnya tekanan udara lingkungan merupakan penyebab utama terjadinya perubahan ketidakseimbangan fisiologi (strain) seorang penyelam.Sedangkan mekanisme adaptif itu sendiri merupakan mekanisme di dalam tubuh manusia sebagai upaya mengurangi stresor tekanan tinggi dan perubahan fisiologi (strain) yang ditimbulkannya, untuk mencapai keadaan "keseimbangan”. Pada keadaan tertentu kondisi keseimbangan tidak dapat dicapai hingga mencapai suatu keadaan patologi. $^{2}$

Pekerjaan penyelaman mempunyai tingkat risiko bahaya yang sangat tinggi, sehingga untuk meningkatkan produktivitas penyelaman dan pelaksanaan penyelaman yang baik dan aman, perlu bekal pengetahuan peningkatan kesadaran tentang kemungkinan bahaya-bahaya yang terjadi di lingkungan udara bertekanan tinggi serta ketaatan memenuhi tata cara peraturan keselamatan kerja dalam penyelaman. Kecerobohan dalam menaati peraturan keselamatan kerja dapat berakibat fatal atau menderita cacat yang berat seumur hidup. ${ }^{3}$

Ketika melakukan latihan fisik termasuk penyelaman, otot-otot tubuh, jantung, dan sirkulasi darah serta sistem pernafasan diaktifkan.Denyut jantung, curah jantung dan konsumsi oksigen meningkat secara linier terhadap intensitas latihan fisik. Peningkatan denyut jantung merupakan respon yang timbul segera pada sistem kardiovaskular terhadap latihan fisik. ${ }^{4}$ Pada penyelaman selama menahan nafas, penyimpanan oksigen dalam paru-paru dan darah berkurang hingga tekanan PO2 dalam otak menjadi begitu rendah dan penyelam berisiko kehilangan kesadaran. ${ }^{5}$

Respon penyelaman manusia bertujuan untuk menghemat oksigen melalui beberapa cara, yaitu vasokonstriksi perifer dan bed kapiler viseral, dan penurunan jumlah penggunaan oksigen perifer dan viseral, dan pembagian oksigen untuk jaringan sensitif oksigen, seperti otak dan jantung. Penurunan denyut jantung (bradikardia) juga dapat mengurangi kebutuhan oksigen dari miokardium, yang bertujuan menghemat simpanan oksigen. ${ }^{6}$ Respon ini dibangkitkan oleh keadaan hipoksia melalui penahanan nafas (apnea). ${ }^{5}$

Seorang penyelam yang menghirup nafas penuh di permukaan akan merasakan paruparunya semakin lama semakin tertekan oleh air di sekelilingnya sewaktu penyelam tersebut turun. Sebelum penyelaman, tekanan udara di dalam paru-paru seimbang dengan tekanan udara atmosfer, yang rata-rata $760 \mathrm{mmHg}$ atau 1 atmosfer pada permukaan laut.Namun pada saat menyelam, udara mengalir ke dalam paru, tekanan udara di dalam paru harus lebih rendah daripada tekanan udara atmosfer.Kondisi tersebut diperoleh dengan membesarnya volume paru.Menurut hukum Boyle tekanan gas di dalam tempat tertutup berbanding terbalik dengan besarnya volume.Bila ukuran tempat diperbesar, tekanan udara di dalamnya turun.Bila ukuran diperkecil, tekanan udara di dalamnya naik. Hukum Boyle berlaku terhadap semua gas-gas di dalam ruangan-ruangan tubuh sewaktu penyelam masuk ke dalam air maupun sewaktu naik ke permukaan. $^{\text {? }}$

Sebagai contoh, apabila seorang penyelam Scuba menghirup napas penuh (6 liter) pada kedalaman 10 meter (2 ATA), menahan napasnya dan naik ke permukaan (1 ATA), udara di dalam dadanya akan berlipat ganda volumenya menjadi 12 liter, maka penyelam tersebut harus menghembuskan 6 liter udara selagi naik untuk menghindari agar paru-parunya tidak meledak. ${ }^{7}$ 
Kontak langsung terhadap air pada dahi, mata dan hidung merupakan stimulus kuat untuk mengaktifkan respon penyelaman.Daerah tersebut dipersarafi oleh nervus trigeminus dimana stimulasi terhadapnya menyebabkan penghambatan pernafasan dan pengaktifan pusat vasomotor dan motoneuron vagal jantung. Respon kardiovaskular ini akan menyebabkan penurunan denyut jantung dan terjadinya vasokontriksi. Reseptor dingin wajah lebih kuat teraktivasi dengan air temperatur rendah $\left(10-15^{0} \mathrm{C}\right) .^{6}$

Sistem pernafasan berhubungan erat dengan sistem kardiovaskular.Sehingga berdasarkan informasi diatas menarik peneliti untuk melihat perubahan hemodinamika yang terjadi pada penyelam terlatih saat menahan nafas yang dinilai melalui denyut nadi.

\section{METODE PENELITIAN}

Penelitian ini merupakan jenis penelitian analitik eksperimental.Peneitian dilaksanakan di Malalayang, Kota Manado, Sulawesi Utara.Populasi dan sampel diambil berdasarkan total sampling yaitu 20 sampel. Kriteria inklusinya yaitu Laki-laki berusia 17-55 tahun dengan IMT normal (18,5-22,9). Sedangkan kriteria eksklusinya yaitu riwayat penyakit jantung dan pernapasan serta hipertensi.Penelitian ini mempunyai variabel independen laki-laki sehat penyelam tradisional danvariabel dependen jumlah denyut nadi.

Jenis data penelitian ini menggunakan data primer berupa jumlah denyut nadi pada arteri radialis. Data dianalisis menggunakan program SPSS v20.0 yang meliputi analisis:

1. Univariat

Untuk mendeskripsikan masing-masing variabel penelitan dan karakteristik sampel penelitian dengan menyajikan distribusinya yang diteliti dengan statistik deskriptif dan disajikan dalam bentuk tabel dan grafik untuk mengetahui proporsi masing-masing variabel.

2. Bivariat

Untuk menguji hipotesis perbedaan jumlah denyut nadi laki-laki sehat penyelam tradisional sebelum, sementara, dan sesudah simulasi penyelaman. Uji statistik yang digunakan adalah uji t sampel berpasangan (paired-samples t test).

Alat dan bahan Penelitian berupa ember berisi air dingin $\left(10-15^{0} \mathrm{C}\right)$, termometer air, Stopwatch, alat tulis, dan laptop. Alur penelitian meliputi:

1. Mengumpulkan data

Pengukuran jumlah denyut nadi saat perendaman wajah

i. Isilah ember dengan air dingin $\left(10-15^{\mathrm{O}} \mathrm{C}\right)$, gunakan es batu untuk mendinginkan. Ukur suhu air dengan termometer.

ii. Sampel duduk di depan ember dengan posisi santai dan tidak banyak bergerak.

iii. Tahap pertama adalah mengukur jumlah denyut nadi sampel saat istirahat tanpa menahan nafas selama 1 menit.

iv. Mendekati akhir tahap pertama, sampel diminta untuk mengambil satu atau dua pernafasan dalam dan menghembuskannya sebagian. Hal ini dibuat tepat setelah 1 menit tahap pertama selesai, dan pasien diminta menahan nafas dan merendam wajah ke dalam air dingin.

v. Tahap kedua adalah mengukur jumlah denyut nadi sampel saat menahan nafas dan merendam wajah dalam air dingin.

vi. Beri kode berupa tepukan pada punggung setiap interval 10 detik untuk mencegah kecemasan.

vii. Tahap ketiga adalah mengukur jumlah denyut nadi sampel saat istirahat selama 1 menit setelah merendam wajah (saat simulasi penyelaman selesai dilakukan). 
2. Mengolah data

Data yang terkumpul diolah melalui tahap cleaning, editing, coding, dan entrydata.

3. Menganalisis data

Data dimasukan ke dalam program SPSS v.20.0 untuk dilakukan analisis data secara univariat dan bivariat.

4. Menyusun kepustakaan dengan mencari literatur-literatur yang berhubungan dengan penelitian

\section{HASIL PENELITIAN}

Penelitian dilakukan pada 20 nelayan profesional yang tinggal di Kelurahan Malalayang 2. Semua sampel penelitian berjenis kelamin laki-laki sehat dengan tekanan darah dalam batas normal sesuai dengan kriteria.

1. Gambaran Sampel

Rentang umur sampel adalah 17 tahun hingga 54 tahun, seperti yang ditunjukan oleh table 1.

Tabel 1. Distribusi Umur

\begin{tabular}{ccc}
\hline Umur (tahun) & $\mathbf{N}$ & $\mathbf{( \% )}$ \\
\hline $17-21$ & 11 & $(55)$ \\
$22-26$ & 7 & $(35)$ \\
$27-31$ & 1 & $(5)$ \\
$>31$ & 1 & $(5)$ \\
\hline
\end{tabular}

Rentang tinggi badan sampel antara $159 \mathrm{~cm}$ hingga $174 \mathrm{~cm}$, seperti yang ditunjukan oleh tabel 2.

Tabel 2. Distribusi Tinggi Badan

\begin{tabular}{ccc}
\hline Tinggi Badan (cm) & $\mathbf{N}$ & $\mathbf{( \% )}$ \\
\hline $159-164$ & 10 & $(50)$ \\
$165-170$ & 5 & $(25)$ \\
$>171$ & 5 & $(25)$ \\
\hline
\end{tabular}

Rentang berat badan antara 45 kg hingga 66 kg, seperti yang ditunjukan oleh tabel 3.

Tabel 3. Distribusi Berat Badan

\begin{tabular}{ccc}
\hline Berat Badan (kg) & $\mathbf{N}$ & $\mathbf{( \% )}$ \\
\hline $45-54$ & 9 & $(45)$ \\
$55-64$ & 9 & $(45)$ \\
$>65$ & 2 & $(10)$ \\
\hline
\end{tabular}

2. Analisis Univariat

Hasil penelitian ini menunjukkan bahwa tahan napas dan perendaman wajah dalam air dingin menyebabkan jumlah denyut nadi menurun, seperti yang ditunjukkan pada tabel 4. 
Tabel 4. Analisis Univariat jumlah denyut nadi

\begin{tabular}{ccccc}
\hline Jumlah Denyut Nadi & Rerata & SD & Min & Max \\
\hline Sebelum & 80 & 9 & 61 & 95 \\
Sementara & 63 & 13 & 41 & 86 \\
Sesudah & 80 & 10 & 60 & 96 \\
\hline
\end{tabular}

3. Analisis Bivariat

Hasil analisis statistik dengan uji t untuk membandingkan jumlah denyut nadi penyelam tradisional pada simulasi penyelaman, seperti yang ditunjukkan pada tabel 5.

Tabel 5. Analisis Bivariat Perbandingan Jumlah Denyut Nadi Dengan Uji t

\begin{tabular}{cccccc}
\hline & Rerata & SD & $95 \%$ CI & P \\
\hline \multirow{2}{*}{ Uji t } & $\begin{array}{c}\text { Jumlah Denyut Nadi } \\
\text { Sebelum dan Sementara }\end{array}$ & 17,1 & 10,2 & $12,4-21,9$ & $\mathbf{0 , 0 0 0 1}$ \\
\cline { 2 - 5 } & $\begin{array}{c}\text { Jumlah Denyut Nadi } \\
\text { Sesudah dan Sementara }\end{array}$ & 16,6 & 10,8 & $11,6-21,7$ & $\mathbf{0 , 0 0 0 1}$ \\
\cline { 2 - 6 } & $\begin{array}{c}\text { Jumlah Denyut Nadi } \\
\text { Sebelum dan Sesudah }\end{array}$ & 0 & 4,3 & $(-1,5)-2,6$ & 0,57 \\
\hline
\end{tabular}

\section{PEMBAHASAN}

Pada penelitian ini didapatkan bahwa jumlah denyut nadi penyelam tradisional saat melalukan simulasi penyelaman lebih rendah secara bermakna dibandingkan dengan saat tidak melakukan simulasi penyelaman. Hal ini sepertinya berlawanan dengan teori yang menyatakan bahwa dalam melakukan aktivitas fisik, jumlah denyut jantung akan meningkat. Jumlah denyut nadi penyelam tradisional saat melakukan simulasi penyelaman ternyata lebih rendah dengan perbedaan 17,1+10,2 (sebelum) dan 16,6+10,8 (sesudah). Hasil ini mendukung hasil penelitian sebelumnya yang menyatakan bahwa jumlah denyut jantung pada penyelam tahan napas dapat turun 20-30 denyutan permenit saat menyelam. Lebih lanjut, menahan napas dan perendaman wajah dalam air dingin dapat menurunkan $25 \%$ denyut jantung, sementara ini menahan napas tanpa perendaman wajah hanya menurunkan $10 \%$ denyut jantung. ${ }^{6}$ Mekanisme yang mendasari kejadian ini adalah adanya respon penyelaman (diving response) pada penyelam.

\section{SIMPULAN}

Pada penelitian ini dapat diambil kesimpulan bahwa ada perbedaan bermakna $(\mathrm{p}=0,0001)$ jumlah denyut nadi pada laki-laki sehat penyelam tradisional pada saat sebelum dengan sementara dan sesudah dengan sementara melakukan simulasi penyelaman dengan tahan napas dan perendaman wajah dalam air dingin. Jumlah denyut nadi pada saat sementara dilakukan simulasi penyelaman secara bermakna lebih rendah dibandingkan dengan denyut nadi sebelum

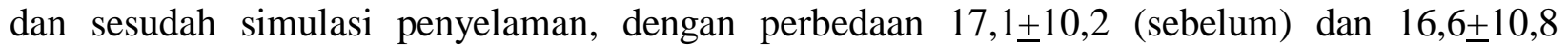
(sesudah). 


\section{DAFTAR PUSTAKA}

1. Herman D, Faisal Y, Fachrial H, Monaldi R. Ambilan oksigen maksimal dan faal paru lakilaki sehat penyelam dan bukan penyelam. J Respir Indo 2011;31(2):61-2.

2. Perhimpunan Kesehatan Hiperbarik Indonesia (PKHI). Pengantar ilmu kesehatan penyelaman. Jakarta; 2000.

3. Hadi N. Tinjauan tentang penyelaman. Oseana 1991;XVI(4):1-12.

4. Mihardja L. Energi dan zat gizi yang diperlukan pada olahraga aerobik dan anaerobik. Majalah Gizmindo 2004;3:9-13.

5. Lindholm P, Nordh J, Gennser M. The heart rate of breath-hold divers during static apnea: effects of competitive stress. UHM 2006;33(2):119-23.

6. Foster GE dan Sheel AW. The human diving response, its function, and it control. Scand J Med Sci Sports 2005;15:3-12.

7. Anonim. Menyelam. 2008 (diakses tanggal 24 September 2013). Diunduh dari:www.coremap.or.id/downloads/menyelam_1158562081.pdf 